\title{
On peace and development economics
}

\section{Shikha Silwal}

Shikha Silwal is Assistant Professor of Economics at Washington and Lee University, Lexington, VA, USA. She may be reached atsilwals@wlu.edu.

\section{Abstract}

Peace and economic development are inextricably linked, yet there is little synergy between researching and teaching the two. The development literature largely assumes peace, even if amidst weak institutions, while the peace economics literature largely assumes the absence of development. This essay presents examples of how integrating the two could help the profession understand better the economics of being poor. Since scholarship flows into what we teach, challenges and opportunities in teaching the economics of war and peace are also discussed.

$\mathrm{N}$ obel Laureates in economics such as Amartya Sen, Theodore Schultz, and Angus Deaton all have argued that a person's wellbeing hardly is captured by income alone. From consumption to happiness to freedom, it is one's subjective wellbeing that affects the types of investments one makes. This subjective wellbeing determines one's quality of life and contributes to one's overall welfare. The circumstances one finds oneself in matter more in determining wellbeing than does one's income. And what better captures the circumstances than the prevalence of war or peace? The freedom exercised to pursue goals - to consume, and to invest in health and education - all are shaped by whether one can reap the benefits of one's actions which, in turn, is dependent on the state of war or peace. Empirical evidence supports the claim that health, education, and people's psychological states are adversely affected by war. ${ }^{1}$

Amartya Sen's broad understanding of human welfare and his particular blending in of ethics and morality into the study of economics stem from his own experience of Hindu-Muslim violence leading to the partition of India into India and Pakistan in 1947. Having witnessed the death of a Muslim man who was a victim of Hindu-Muslim riot, Sen observes how freedom is fundamental to human dignity and welfare. Freedom, he argues, is both a means and end of development. Freedom, such as freedom to satisfy one's basic needs and freedom to pursue one's goals, is both instrumental and intrinsic to development. It is instrumental in that it can lead to the fulfillment of other goals (higher income, for example) and intrinsic in that freedom is valuable in and of itself. He also argues that instrumental and intrinsic views of freedom shape policies, which then help determine the overall wellbeing of citizens. $^{2}$

Sen's analysis of freedom and development incorporates the relation between war and development indirectly; other work does so directly. In an article published in 2008 ("Violence, Identity, and Poverty"), he rejects the prevalence in conflict studies of treating subjects as if they had but a singular identity. He points out several ways in which identity is complex, as it intersects with gender, class, religion, etc. In laying out his critique of empirical analyses of war and peace, Sen introduces nuances of morality, ethics, and development into the study of war and peace. Although it remains a challenge to cultivate those ideas into testable hypotheses, his is a prominent example of how the two fields of peace and development studies could fuse to further our understanding of war, peace, poverty, and development.

Numerous empirical studies uncover the effects of war on economic development and vice versa. Thanks to survey and administrative data, such as the Demography and Health Survey and Living Standard Measurement Survey, studies have examined macro and micro-level effects of war on long-term economic development, education, and labor market outcomes of children forcefully conscripted or indirectly exposed to violence, and on physical and mental health. ${ }^{3}$

Despite advances, more is needed to bridge the two fields. Topics such as human migration and the role and quality of institutions that have received considerable attention in the development literature have not fully crossed over to war and peace studies. Migration studies, for instance, long have analyzed push and pull factors contributing to the movement of people in space and time. One such push factor is war. More recently, spillover effects of migration on political and cultural outcomes in the migrant's country of origin have been examined. Similarly, an understanding of the importance of institutions for economic development, and vice versa, has been developed. ${ }^{4}$

In the conflict and peace literature, the role of the diaspora in precipitating violence in the country of origin is well- 
recognized. The studies, however, do not fully exploit theories of migration and international migration patterns. Neither do migration studies bring in diasporas as possible confounding factors in the migration decisions. Institutions, on the other hand, have received little-to-no attention in conflict studies. One of the deepest legacies of war is the effect it has on institutions. Nevertheless, how institutions shape wars and how wars in turn affect institutions remain largely unexplored. Indeed, our understanding of the functioning of courts, rule of law, and transitional justice in the context of developing countries is at its infancy. A World Bank initiative to strengthen institutions and help make them more effective and accountable suggests promising future in this area. In the next section, I highlight some of the ways in which research on these topics could cross over to help us grasp the development and conflict nexus more fully. ${ }^{5}$

\section{International migration and remittances}

Developing economies, cursed by exploitable natural resources and crippled by weak institutions, are vulnerable to upsurges in war. Arguably, one of the ignored exploitable resources is their abundance of unskilled labor whose migration contributes to income increases (through remittances) and political change in the countries of origin. While geographical spillover of democracy and political changes brought out by international migration is prevalent in migration studies, they have three key limitations: First, most of the studies assume migration is voluntary; second, the presence of war or of any internal conflict is seen as a push factor without full consideration of the role of the diaspora in the destination country; and third, the migrant's origin and destination countries are treated as two different sets of countries without allowing the unobservable characteristics of the two to be correlated with one another. ${ }^{6}$

One of the largest and most rapid involuntary migrations in human history resulted from the partition of India into India and Pakistan in 1947. One study estimated that within four years after the partition approximately 14.5 million people migrated into India, Pakistan, and would-be Bangladesh. The estimate actually calculates an approximate outflow of 17.9 million people, with the remaining 3.4 million people unaccounted for and presumed to have perished. ${ }^{7}$

Naturally, this rapid and large-scale migration played a significant role in shaping the economic and political landscape of the subcontinent. On average, Hindus and Sikhs migrating from Pakistan to India left their banking and finance sector jobs to settle in India's urban centers. Conversely, Muslims fleeing India for Pakistan tended to be less educated and settled in Pakistan's agriculture sector. Consequent to this demographic shift, literacy rates increased in India and decreased in
The essay illustrates research and teaching needs to help integrate the study of economic development with the economics of conflict, war, and peace. For instance, while the topics of migration and associated income remittances to the country of origin now are commonplace in studies of economic development, they frequently overlook involuntary migration factors during violent conflict.

Pakistan. The violence that ensued during this period created a deep divide between the two countries that continues to this day. ${ }^{8}$

This example of a large-scale and rapid migration and it's contribution to shaping the geography, economy, and polity of countries or subregions is not unique. Most conflicts result in rapid and large outflows of people. For 2015, the Migration Policy Institute estimates some 244 million international migrants. About 18 million emigrated from fragile states in 2000 alone. Perhaps surprisingly, migrants from a fragile stage predominantly migrate to another fragile state. Despite this, there they are likely to earn higher income than in their country of origin. Researchers are only beginning to understand the long-term effects of such forced migration. This is an example where migration studies could better account for push factors such as war and partition and conflict studies could consider migration models to understand individual-level decisions in the context of forced migration and to gauge the long-term effects of such events. ${ }^{9}$

A migration decision is based, in part, on proximity (an estimation of the cost of migration) and cultural similarity. Proximity often is measured by distance. However, distance is a relative concept. Falling fuel prices or improved infrastructure can distort the absolute sense of distance between any two locations. For example, the physical distance from India to the United States is constant at any point in time. However, their relative distance has decreased so considerably over the years that it might well be the case that their relative distance is shorter than that between India and other countries in the region. Significant advances in internet-based telecommunications have reduced the cost of communication between migrants and their families back home. The better the network, the lower the calling rates, and the more accessible the internet, the smaller is the relative distance between any two countries. Hence, distance should reflect the state of telecommunication and overall connectivity between countries.

Furthermore, if migrants select destination countries based on cultural similarity, then cultural factors such as religion and language enter empirical analysis as unobservable factors unless explicitly accounted for. Yet, in research practice, the origin and destination countries tend to be treated as two 
unrelated observations.

Migration and conflict studies, therefore, could co-evolve by addressing each others' limitations. Well-established migration studies might be revisited with a better understanding of forced migration and the nonrandom selection of destination countries. Likewise, reassessing conflict studies to better incorporate the tools and theories of migration studies may help us understand a human phenomenon that plays a key role in development and peace.

Another important aspect of increased international migration concerns the flow of remittances. Worldwide remittance flows totaled USD582 billion in 2015, with USD432 billion to low- or middle-income countries. Remittances dwarf official development assistance, which was slightly over USD100 billion in 2015. For some recipient countries, such as Nepal and Liberia, remittances are over 30 percent of GDP. Remittances to Tajikistan, Kyrgyzstan, Haiti, Moldova, and Samoa accounted for more than 20 percent of GDP. India and China, top remittance recipient countries in terms of the absolute dollar amount, each received over USD65 billion in 2015. Studies have shown that remittances contribute to improved health and education, while also enabling political change. The nature and role of remittances, therefore, are key policy topics in developing countries, the proper management of which will be a concern to both development and peace scholars. ${ }^{10}$

\section{Teaching the economics of war and peace}

According to a survey, in 2007 only thirteen percent of thirtyeight undergraduate economic development syllabi from top U.S. colleges covered the topic of war and peace. Prominent Economic Development textbooks hardly mention war and peace, relegating the topics to footnotes in a few chapters. Hence, war and peace are often overlooked as key topics in the teaching of economic development. Despite certain challenges, classes aimed at economic development can creatively incorporate the topics of conflict, war, and peace. As my own teaching experience lies at the undergraduate level at a liberal arts institution, I limit my comments to teaching economic development and the economics of war and peace at liberal arts colleges. $^{11}$

Very few economics faculty teach an introductory course on the economics of war and peace. For those of us who teach such a course regularly, there is a growing need to adopt a common set of course objectives and teaching tools so that there is a clear understanding of what the course aims to accomplish. One big challenge is lack of consensus as to what the core of such a course is. Other important questions loom large. For example, what basic concepts and tools should undergraduate students acquire as learning outcomes in such a course?

Not only should there be a common set of readings, but we also need a common approach to teaching it. Should the course follow the topical approach of Anderton and Carter's Principles of Conflict Economics (2009), a key resource in teaching the economics of war and peace, or should the course be more literature based? And who, exactly, is the primary audience of students for such a course? If the goal is to cast the net widely, then the course needs to be pitched to a general audience, presumably at a relatively nontechnical level so as to appeal to a broader range of students. Whether students major in economics or not, all are (or will be) economic consumers and producers in their day-to-day lives. A course that engages a wide audience could help non-majors appreciate the utility of economics in addressing complex real world problems, including those of development and peace. One disadvantage of a general course, however, is that it cannot fully employ economic tools and methods. Following Anderton and Carter's textbook, an upper-level course can be imagined to revisit some of the tools covered in intermediate-level microeconomics and apply them to the study of war and peace. Ideally, however, we would have a sequence of courses on economics of war and peace to address these concerns.

One can imagine an introductory course that is friendly enough for a general audience. The course could cover concepts typically seen in a Principles of Microeconomics class and apply them to the study of war and peace. It would give students a general sense of how economists study this topic and engage them in policy discussions. At a minimum, the course should introduce students to the history of economic thought and some key scholars of the subfield. Subsequently, an intermediate-level course then employs intermediate-level microeconomics and econometrics, both to model economies with war and peace and to understand the empirical findings on the topics.

Lastly, one can also conceive of courses that combine both development economics and peace economics. A hypothetical Peace and Prosperity course could capture literature-based teaching of development economics while having the theory grounded in peace economics. By analogy, in a course on Economics of Culture, one starts with cultural elements, such as identity and trust, that shape individual preferences. Those preferences, in turn, carry direct implications for the resulting institutions that shape an economy by creating specific sets of incentives to affect the functioning of markets. Likewise, a course that combines both development economics and peace economics could pin its roots in peace, the basis which carries ramifications for development. Recognizing these two fields as 
inextricably linked opens doors to designing creative courses that could capture a more complete picture of developing countries.

\section{Concluding remarks}

With the opening words of his Nobel Prize award lecture, Theodore Schultz noted that "most of the people in the world are poor, so if we knew the economics of being poor we would know much of the economics that really matters. Most of the world's poor people earn their living from agriculture, so if we knew the economics of agriculture we would know much of the economics of being poor." Not only are most people in the world poor but they are trapped in a vicious cycle of poverty and violence. So if we knew the economics of war and peace, perhaps we would know much more about the economics of being poor. ${ }^{12}$

This essay assumes that violent conflict is an inherent problem facing developing countries. It need not be so. The concept of violence or peace contained within geographical boundaries of countries is becoming less relevant. As people move across countries and continents to seek refuge, as violence against nationals of a country can be perpetrated in any country across the globe, and as instability in one part of the world reverberates to other countries, war and peace becomes a problem common to everyone. Notwithstanding the complexities imbedded in it, analyzing the economic roots of war and peace is a necessary step toward the understanding of economic development.

\section{Notes}

1. Nobel Laureates: For the Laureates' profiles, see www.nobelprize.org/nobel_prizes/economic-sciences/. Empirical evidence: See, e.g., Hanushek and Woessmann (2008), Bundervoet, Verwimp, and Akresh (2009), Blattman and Annan (2010), Shemyakina (2011), Leon (2012), Singh and Shemyakina (2015), and Silwal (2016).

2. On Sen, see Sen (2001).

3. See, e.g., Miguel, Satyanath, and Sergenti (2004) on the relation between income shock and civil unrest, Miguel and Roland (2011) on the long-run effects of bombing Vietnam, and Brauer and Dunne (2012) for a detailed discussion of macroeconomic effects of violence and associated policy implications. Also see Blattman and Miguel (2010) for a review of the civil war literature.

4. Push and pull factors: See, e.g., Özden, Rapopart, and Schiff (2011) for an overview of data and the advancement in international migration and development research. Spillover effects: Grieco (1998), Spilimbergo (2009), Docquier and Rapoport (2012), LeSage and Ha (2012), Pfutze (2012), Mahmoud, et al. (2013), Chauvet and Mercier (2014), and Docquiwe, et al. (2016). Institutions: See, e.g., Guiso,
Sapienza, and Zingales (2006) for a study of the effects of culture on economic outcomes and Tabellini (2007) for a discussion of the relations among culture, institutions, and economic development.

5. Largely unexplored: Blattman and Miguel (2010). World Bank: For details, see its Law, Justice, and Development site http://www.worldbank.org/en/topic/lawjusticeanddevelopment.

6. Unskilled labor: Prichett (2006) refers to unskilled labor as the primary asset of the poor. Income and political change: Blattman and Miguel (2010). Limitations: LeSage and $\mathrm{Ha}$ (2012) is an exception.

7. Estimated: Khwaja, Milan, and Bharadwaj (2008).

8. See Dalrymple (2015) for a discussion of India's partition on current Indo-Pakistani relations.

9. Migration Policy Institute: See www.migrationpolicy.org/ programs/data-hub/international-migration-statistics [accessed 20 December 2016]. Fragile states: Hoeffler (2013).

10. Remittance flows: See the Migration Policy Institute's www.migrationpolicy.org/programs/data-hub/internationalmigration-statistics [accessed 20 December 2016]. Health and education: For instance, Bansak, Chezum, and Giri (2015) analyze the effects of remittances on household expenditure on education in Nepal. Political changes: Spilimbergo (2009), Pfutze (2012), Mahmoud, et al. (2013), Chauvet and Mercier (2014), and Docquier, et al. (2016) study spillover effects of international migration on home-country institutions.

11. Survey: Blattman and Miguel (2010).

12. Quote: Schultz (1980). The lecture is also available at https://www.nobelprize.org/nobel_prizes/economic-sciences/ laureates/1979/schultz-lecture.html [accessed 3 September 2017].

\section{References}

Anderton, C.H. and J.R. Carter. 2009. Principles of Conflict Economics. New York: Cambridge University Press. https://doi.org/10.1017/CBO9780511813474

Bansak, C., B. Chezum, and A. Giri. 2015. "Remittances, School Quality, and Household Education Expenditures in Nepal." IZA Journal of Migration. Vol. 4, Article 16. Available at https://izajodm.springeropen.com/articles/ 10.1186/s40176-015-0041-z [accessed 2 September 2017].

Blattman, C. and J. Annan. 2010. "The Consequences of Child Soldiering." Review of Economics and Statistics. Vol. 92, No. 4, pp. 882-898. https://doi.org/10.1162/REST_a_00036

Blattman, C. and E. Miguel. 2010. "Civil War." Journal of Economic Literature. Vol. 48, No. 1, pp. 3-57. https://doi.org/10.1257/jel.48.1.3

Brauer, J. and J. Paul Dunne. 2012. Peace Economics: A Macroeconomic Primer for Violence-Afflicted States. Washington, D.C.: United States Institute of Peace Press.

Bundervoet, T., P. Verwimp, and R. Akresh. 2009. "Health and Civil War in Rural Burundi." Journal of Human Resources. Vol. 44, No. 2, pp. 536-563. 
https://doi.org/10.3368/jhr.44.2.536

Camacho, A. 2008. "Stress and Birth Weight: Evidence from Terrorist Attacks." American Economic Review. Vol. 98, No. 2, pp. 511-515. https://doi.org/10.1257/aer.98.2.511

Chauvet, L. and M. Mercier. 2014. "Do Return Migrants Transfer Political Norms to their Origin Country? Evidence from Mali." Journal of Comparative Economics. Vol. 42, No. 3, pp. 630-651. https://doi.org/10.1016/j.jce.2014.01.001

Dalrymple, W. 2015. "The Great Divide: The Violent Legacy of Indian Partition." The New Yorker. 29 June 2015. http://www.newyorker.com/magazine/2015/06/29/the-gre at-divide-books-dalrymple [accessed 1 September 2017].

Docquier, F. and H. Rapoport. 2012. "Globalization, Brain Drain, and Development." Journal of Economic Literature. Vol. 50, No. 3, pp. 681-730. https://doi.org/10.1257/jel.50.3.681

Docquier, F., E. Lodigiani, H. Rapoport, and M. Schiff. 2016. "Emigration and Democracy." Journal of Development Economics. Vol. 120, pp. 209-223. https://doi.org/10.1016/j.jdeveco.2015.12.001

Grieco, E.M. 1998. "The Effects of Migration on the Establishment of Networks: Caste Disintegration and Reformation Among the Indians of Fiji." International Migration Review. Vol. 32, No. 3, pp. 704-736. https://doi.org/10.2307/2547769

Guiso, L., P. Sapienza, and L. Zingales. 2006. "Does Culture Affect Economic Outcomes?" Journal of Economic Perspectives. Vol. 20, No. 2, pp. 23-48. https://doi.org/10.1257/jep.20.2.23

Hanushek, E.A. and L. Woessmann. 2008. "The Role of Cognitive Skills in Economic Development." Journal of Economic Literature. Vol. 46, No. 3, pp. 607-668. https://doi.org/10.1257/jel.46.3.607

Hoeffler, A. 2013. "Out of the Frying Pan into the Fire? Migration from Fragile States to Fragile States." OECD Development Co-operation Working Paper 9/2013. Paris: OECD. https://doi.org/10.1787/5k49dffmjpmv-en

Khwaja, A., A. Mian, and P. Bharadwaj. 2008. "The Big March: Migratory Flows After the Partition of India." Economic and Political Weekly. 30 August 2008. Vol. 43, No. 35, pp. 39-49.

Leon, G. 2012. "Civil Conflict and Human Capital Accumulation: The Long-Term Effects of Political Violence in Peru." Journal of Human Resources. Vol. 47, No. 4, pp. 991-1022. https://doi.org/10.3368/jhr.47.4.991

LeSage, J.P. and C.L. Ha. 2012. "The Impact of Migration on Social Capital: Do Migrants Take their Bowling Balls with Them?" Growth and Change. Vol. 43, No. 1, pp. 1-26. https://doi.org/10.1111/j.1468-2257.2011.00575.x

Mahmoud, O.T., H. Rapoport, A. Steinmayr, and C. Trebesch. 2013. "The Effect of Labor Migration on the Diffusion of Democracy: Evidence from a Former Soviet Republic."
Centre for Research and Analysis of Migration. Discussion Paper Series CDP No. 20/13. London: University College London. Available at http:/www.cream-migration.org/ publ_uploads/CDP_20_13.pdf [accessed 2 September 2017].

Miguel, E. and G. Roland. 2011. "The Long-Run Impact of Bombing Vietnam." Journal of Development Economics. Vol. 96, No. 1, pp. 1-15.

https://doi.org/10.1016/j.jdeveco.2010.07.004

Miguel, E., S. Satyanath, and E. Sergenti. 2004. "Economic Shocks and Civil Conflict: An Instrumental Variables Approach." Journal of Political Economy. Vol. 112, No. 4, pp. $725-753$.

https://doi.org/10.1086/421174

Özden, Ç., H. Rapoport, and M. Schiff. 2011. "Five Questions on International Migration and Development." The World Bank Economic Review. Vol. 25, No. 1, pp. 1-11. https://doi.org/10.1093/wber/lhr021

Pfutze, T. 2012. "Does Migration Promote Democratization? Evidence from the Mexican Transition." Journal of Comparative Economics. Vol. 40, No. 2, pp. 159-175. https://doi.org/10.1016/j.jce.2012.01.004

Pritchett, L. 2006. "Let Their People Come: Breaking the Gridlock on International Labor Mobility." Washington, D.C.: Center for Global Development.

Schultz, T.W. 1980. "Nobel Lecture: The Economics of Being Poor." Journal of Political Economy. Vol. 88, No. 4, pp. 639-651. https://doi.org/10.1086/260895

Sen, A. 2001. Development as Freedom. Oxford, UK: Oxford University Press.

Sen, A. 2008. "Violence, Identity, and Poverty." Journal of Peace Research. Vol. 45, No. 1, pp. 5-15. https://doi.org/10.1177/0022343307084920

Shemyakina, O. 2011. "The Effect of Armed Conflict on Accumulation of Schooling: Results from Tajikistan." Journal of Development Economics. Vol. 95, No. 2, pp. 186-200. https://doi.org/10.1016/j.jdeveco.2010.05.002

Silwal, S. 2016. "Resilience Amidst Conflict? The Effect of Civil War Exposure on Secondary Education." International Journal of Development and Conflict. Vol. 6, No. 2, pp. 97-120.

Singh, P. and O. Shemyakina. 2016. "Gender-Differential Effects of Terrorism on Education: The Case of the 1981-1993 Punjab Insurgency." Economics of Education Review. Vol. 54, pp. 185-210. https://doi.org/10.1016/j.econedurev.2016.02.003

Spilimbergo, A. 2009. "Democracy and Foreign Education." American Economic Review. Vol. 99, No. 1, pp. 528-543. https://doi.org/10.1257/aer.99.1.528

Tabellini, G. 2008. "Presidential Address: Institutions and Culture." Journal of the European Economic Association. Vol. 6, Nos. 2-3, pp. 255-294. https://doi.org/10.1162/JEEA.2008.6.2-3.255 